Article

\title{
Runoff and Sediment Yield Variations in Response to Precipitation Changes: A Case Study of Xichuan Watershed in the Loess Plateau, China
}

\author{
Tianhong Li ${ }^{1,2, *}$ and Yuan Gao ${ }^{1,2}$
}

1 College of Environmental Sciences and Engineering, Peking University, Beijing 100871, China; E-Mail: gaoyuan@iee.pku.edu.cn

2 Key Laboratory of Water and Sediment Sciences, Ministry of Education, Beijing 100871, China

* Author to whom correspondence should be addressed; E-Mail: 1th@pku.edu.cn; Tel.: +86-10-6275-3351.

Academic Editors: Yingkui Li and Michael A. Urban

Received: 22 August 2015 / Accepted: 13 October 2015 / Published: 19 October 2015

\begin{abstract}
The impacts of climate change on hydrological cycles and water resource distribution is particularly concerned with environmentally vulnerable areas, such as the Loess Plateau, where precipitation scarcity leads to or intensifies serious water related problems including water resource shortages, land degradation, and serious soil erosion. Based on a geographical information system (GIS), and using gauged hydrological data from 2001 to 2010, digital land-use and soil maps from 2005, a Soil and Water Assessment Tool (SWAT) model was applied to the Xichuan Watershed, a typical hilly-gullied area in the Loess Plateau, China. The relative error, coefficient of determination, and Nash-Sutcliffe coefficient were used to analyze the accuracy of runoffs and sediment yields simulated by the model. Runoff and sediment yield variations were analyzed under different precipitation scenarios. The increases in runoff and sediment with increased precipitation were greater than their decreases with reduced precipitation, and runoff was more sensitive to the variations of precipitation than was sediment yield. The coefficients of variation ( $\mathrm{Cvs})$ of the runoff and sediment yield increased with increasing precipitation, and the $\mathrm{Cv}$ of the sediment yield was more sensitive to small rainfall. The annual runoff and sediment yield fluctuated greatly, and their variation ranges and Cvs were large when precipitation increased by $20 \%$. The results provide local decision makers with scientific references for water resource utilization and soil and water conservation.
\end{abstract}


Keywords: SWAT model; precipitation; runoff; sediment yield; simulation; the Xichuan River; the Loess Plateau

\section{Introduction}

Climate change as a result of both natural factors and human activities is altering the earth's hydrologic cycles to various degrees $[1,2]$. Climate change affects hydrology mainly through changes in precipitation, temperature, and evaporation $[3,4]$, and it subsequently influences the temporal-spatial distributions of runoff and sediment, as well as the patterns of runoff and sediment transport [5]. The impacts of climate change on water resources and the hydrologic cycles have long been a focus of the international community [6,7]. Research on this issue began as early as the 1980s. In 1985, the World Meteorological Organization (WMO) published a summary report of their study of the impacts of climate change on hydrology and water resources and proposed several evaluation and test methods. In 1987, the WMO proposed analyzing the sensitivity of hydrology and water resources to climate change. This issue was also discussed in the 2007 international conference of the International Union of Geodesy and Geophysics (IUGG). The Intergovernmental Panel on Climate Change (IPCC) of the United Nations analyzed the impacts of climate change on hydrology and water resources from 1990 to 2007. In its technical report [8], the IPCC highlighted that the global and regional water resource problems caused by climate change are crucial issues. Changes in precipitation and temperature have significant effects on runoff and water availability, particularly in semiarid and arid regions [9].

China has always considered the impacts of climate change on water resources to be important and has actively carried out a series of scientific studies to support research on the impact of the changing environment (due to global changes and human activities) on water cycles [5,10]. For instance, the National Planning Outline for Mid- and Long-term Scientific and Technological Development (2006-2020) issued by the State Council of China in 2006 pointed out that research on the impacts of global climate change in China is a focus, with special emphasis on the impacts of climate change on hydrologic cycles and regional water resources, especially in arid regions with fragile ecological environments [11].

Currently, studies of the impacts of climate change on runoff and sediment mainly focus on two aspects. Some studies analyze the changes in the temporal-spatial distributions of runoff and sediment and the patterns of runoff and sediment transport that are caused by changes in climate factors, such as precipitation and temperature, whereas other studies analyze the trends of the changes in runoff and sediment under future climate change scenarios. The main method for quantitatively evaluating and studying the impacts of climate change on runoff and sediment is to use watershed hydrological models. The most commonly used models are statistical regression models, water balance models, and distributed physical models $[9,12]$. Of these models, the Soil and Water Assessment Tool (SWAT) [13], which was developed by the US Department of Agriculture in the 1990s, has been widely applied to watersheds around the world [14-20]. There are two types of predicted future climate change scenarios. First, changes in temperature, precipitation, and evaporation are hypothesized based on the trends and ranges of the meteorological changes in the study area, as well as specialized knowledge, experience, and the time-series 
statistical analysis method, which is easy to design and apply [21-23]; Second, different climate change scenarios can be simulated using models, such as the General Circulation Models [19,24].

Previous studies have shown that the precipitation in the Yellow River Basin has decreased significantly since the 1970s [10,25] although variation trends may differ in sub-basins. Precipitation is the main source of runoff and one of the driving factors of soil and water losses in the Loess Plateau [26,27], where water resources are scarce. Therefore, in the context of global climate change, studying the impacts of changes in precipitation on the runoff and sediment production in the Yellow River Basin is important for the sustainable utilization of water resources. Most previous studies of the impacts of changes in precipitation on water resources in the Yellow River Basin have focused on the entire basin [28,29] or the basin at relatively large scales [30-32]. Relatively few studies have focused on small watersheds. In addition, most studies have focused on the impact of precipitation on the runoff and have rarely investigated the impact of precipitation on the sediment yield. In fact, high sediment content is an important and unique characteristic of the rivers in the Loess Plateau, China. Sediment transport requires a considerable amount of water [33] and competes with other water uses. Thus, it is imperative to consider sediment when studying the water resource problems of these rivers.

This study used the Xichuan Watershed, a typical small basin in the hilly and gully area in the Loess Plateau, as a target area, and used ArcGIS, MATLAB, and SPAW [34,35] to process observed meteorological and hydrological data. Then, a localized SWAT model was constructed, calibrated, and validated. Using the SWAT model under different precipitation scenarios, the study quantitatively predicted the impacts of changes in precipitation on the runoff and sediment yield in this small watershed and analyzed the characteristics of the changes in runoff and sediment production with the aim of providing a scientific basis for the management and sustainable utilization of water resources in basins that are similar to the study area.

\section{Methodology}

Based on the spatial and attribute data, including meteorological data, hydrological data, soil map, land use map, and a digital elevation model (DEM), this study investigated the characteristics of the changes in the precipitation, runoff, and sediment yield in the study area. Spatial and attribute databases of the SWAT model were developed. After determining the parameters of the SWAT model and verifying the predicted results from the model, we quantitatively analyzed the impacts of changes in precipitation on the runoff and sediment production in the study area using precipitation change scenarios. Figure 1 shows the technical workflow of the study.

This study used AVSWAT, developed by integrating the SWAT into ArcView for the analysis. AVSWAT has powerful spatial analysis and processing functions and is convenient to use. The SWAT model consists of three sub-models: the hydrological process sub-model, the soil erosion sub-model and the pollution load sub-model. This study mainly uses the hydrological process and the soil erosion sub-models. 


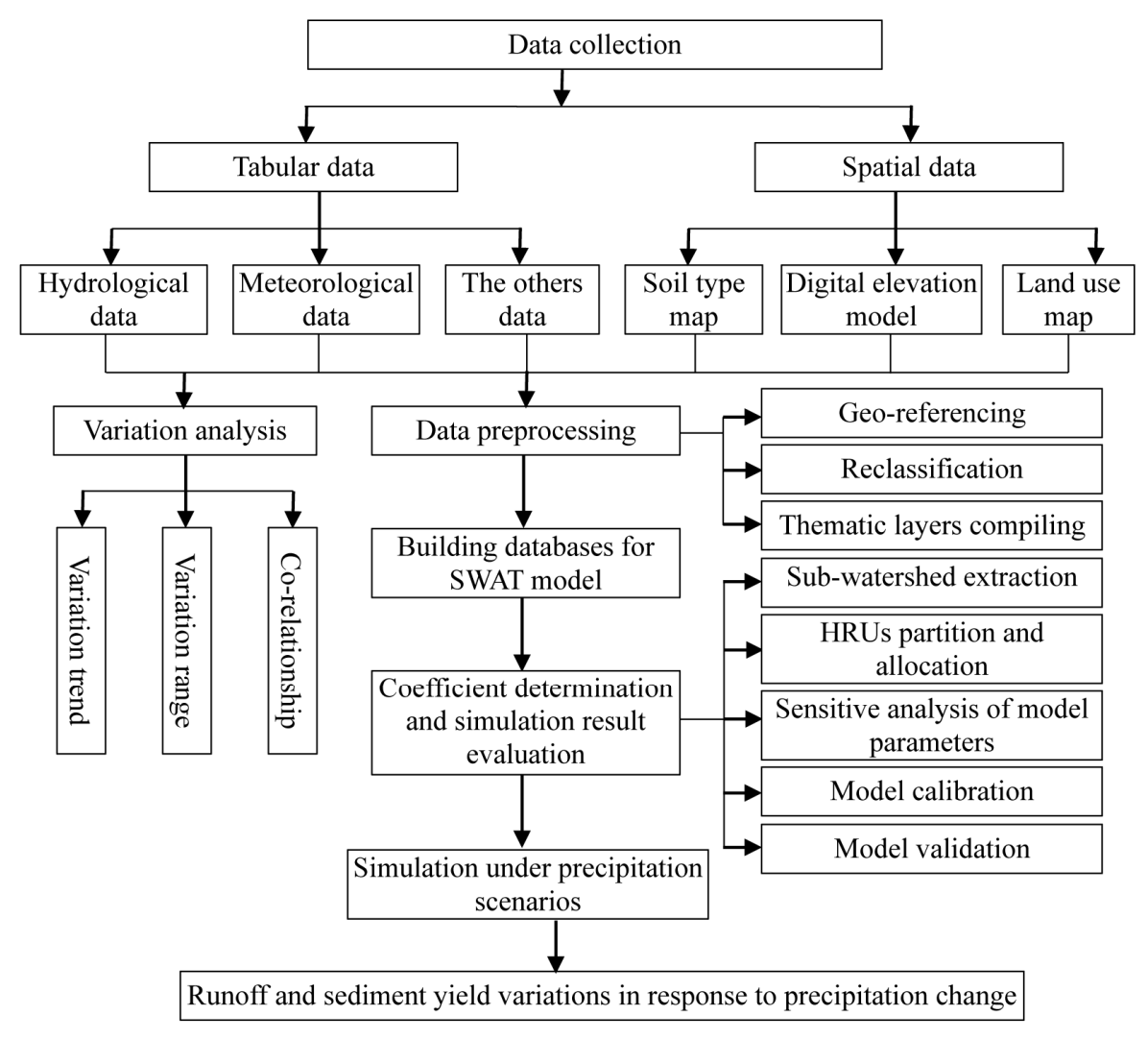

Figure 1. Technical workflow of this study.

\subsection{Study Area}

The Xichuan River is a tributary of the Yanhe River (a tributary of the Yellow River) with a total length of $61.5 \mathrm{~km}$. The Xichuan Watershed is located west of the Yanhe River Basin between $108^{\circ} 50^{\prime} \mathrm{E}$ and $109^{\circ} 20^{\prime} \mathrm{E}$ and between $36^{\circ} 30^{\prime} \mathrm{N}$ and $36^{\circ} 45^{\prime} \mathrm{N}$, covering an area of $801 \mathrm{~km}^{2}$ [36]. The mean runoff of the watershed was $169.04 \times 10^{6} \mathrm{~m}^{3}$ from 2001 to 2010 . The river originates in Caofeng Village, Zhidan Town in Zhidan County and flows past Xihekou Village, Zhuanyaowan Town and Gaoqiao Village in Ansai County and Zaoyuan Village in the Baota District and eventually flows into the Yanhe River near Shifogou in the Baota District. The Zaoyuan Hydrological Station (ZHS) is located $13 \mathrm{~km}$ upstream from the mouth of the Xichuan River, and it controls $90 \%$ area $\left(719 \mathrm{~km}^{2}\right)$ of the whole watershed (Figure 2).

The Xichuan Watershed has a continental monsoon climate where winters are cold and dry with little precipitation, whereas summers are warm with abundant precipitation. Precipitation is unevenly distributed and mainly concentrated in the summer and fall, accounting for $54.3 \%$ and $27.7 \%$ of the total annual precipitation. Floods in this watershed have relatively short durations, rising and falling suddenly with high sediment concentrations [37].

The soil types in this watershed include yellow loessial soil, red clay soil, alluvial soil, and dark loessial soil. The yellow loessial soil, developed from the parent loess, is the main soil type, covering more than $80 \%$ of the total basin area. The vegetation coverage of the watershed is very low, belonging to the forest steppe zone. Both natural and artificial vegetation types are present, mainly consisting of crops, evergreen coniferous forests, deciduous coniferous forests, deciduous broad-leaved forests, shrubs, and grasslands. 

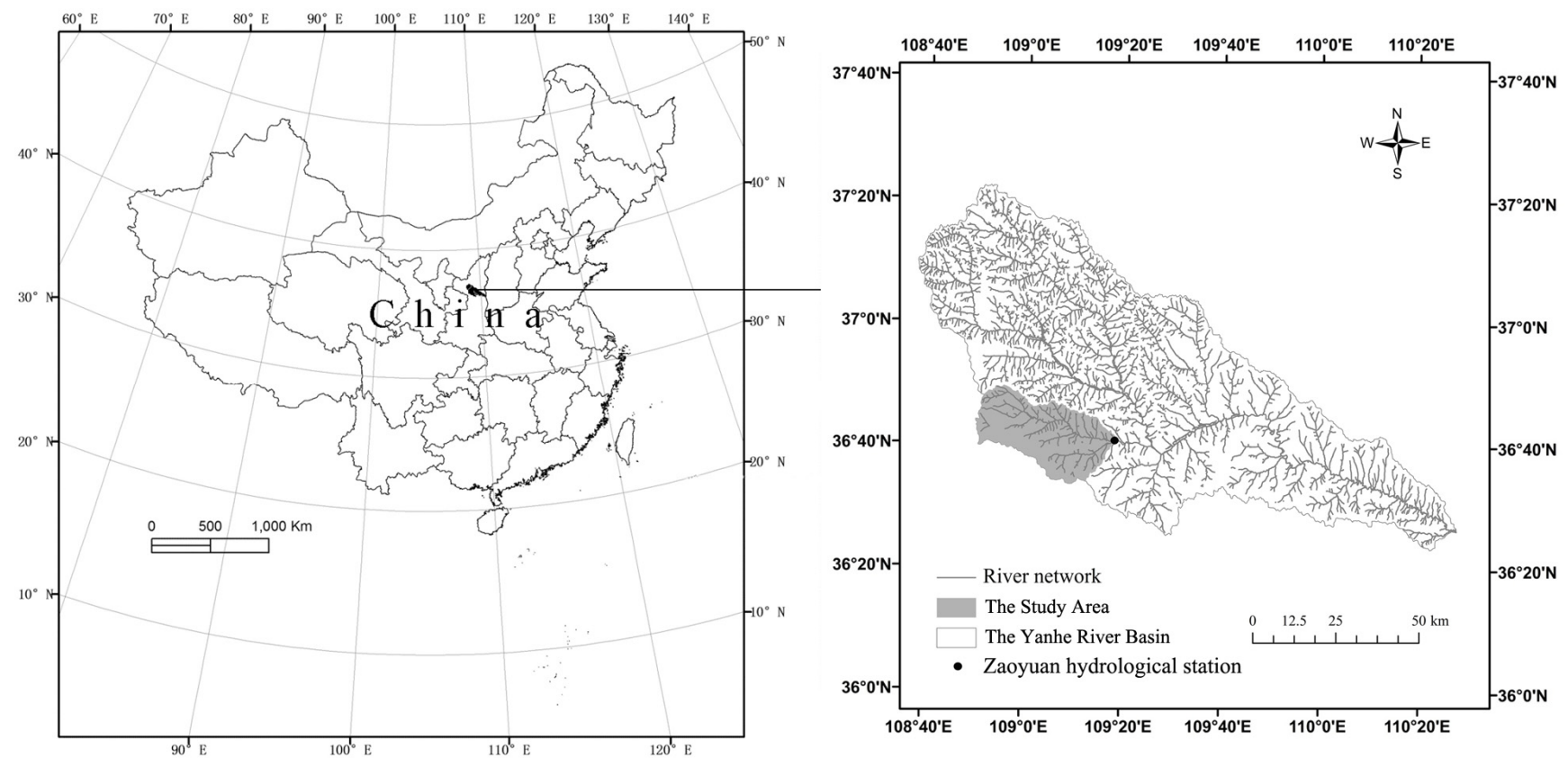

Figure 2. Location of the study area.

More than $80 \%$ of the basin area suffers soil erosion by water. The multi-year mean sediment discharge is $1330.2 \times 10^{4} \mathrm{t} / \mathrm{a}$. Since the $1970 \mathrm{~s}$, a series of water and soil conservation and ecological construction projects have been implemented and have substantially improved the ecological environment in the watershed [38].

\subsection{Data and Data Preprocessing}

The main data used in this study included Digital Elevation Model (DEM) data, a land use map, a soil type map, precipitation data, temperature data, and the boundary of the Yanhe River basin. Table 1 lists the data descriptions and sources.

Table 1. List of data that were used in this study.

\begin{tabular}{ccc}
\hline Data Type & Temporal/Spatial Resolution & Source \\
\hline DEM data & Grid format, 30 m/grid & $\begin{array}{c}\text { Data Application Environment Sharing } \\
\text { Platform of the Chinese Academy of Sciences }\end{array}$ \\
\hline Land use map & At the scale of 1:100,000, compiled at 2005 & $\begin{array}{c}\text { Data Application Environment Sharing } \\
\text { Platform of the Chinese Academy of Sciences }\end{array}$ \\
\hline Soil type map & At the scale of 1:1,000,000, compiled at 2005 & $\begin{array}{c}\text { Data Application Environment Sharing } \\
\text { Platform of the Chinese Academy of Sciences }\end{array}$ \\
\hline $\begin{array}{c}\text { Meteorological } \\
\text { data }\end{array}$ & $\begin{array}{c}\text { Daily precipitation, daily maximum temperature and } \\
\text { daily minimum temperature between 1990 and 2010 }\end{array}$ & $\begin{array}{c}\text { China Meteorological Data Sharing } \\
\text { Service Website }\end{array}$ \\
\hline $\begin{array}{c}\text { Runoff and } \\
\text { sediment yield }\end{array}$ & $\begin{array}{c}\text { Monthly runoff and sediment yield } \\
\text { between 2001 and 2010 }\end{array}$ & $\begin{array}{c}\text { The Zaoyuan Meteorological Station } \\
\text { in the Yan'an City }\end{array}$ \\
\hline
\end{tabular}

The data required for the SWAT model included geospatial data, a non-spatial attribute database, meteorological data, and hydrological and sediment data for model calibration and verification. Spatial data processing, grid calculations, and interpolations were conducted using ArcGIS, and the statistical 
analysis was performed using Excel. All spatial data used in the SWAT were converted to the Albers equal-area conic projection. The whole area was divided into 31 sub-basins using the DEM and each sub-basin contained 5-16 hydrological response units (HRUs), which is the basic unit in SWAT model.

\subsection{SWAT Model Development}

\subsubsection{Model Construction}

The SWAT model requires the land use classification scheme developed by the US Geological Survey (USGS). It also requires the auxiliary land use attributes with parameters provided by the USGS. The land use map used in this study had to be reclassified to meet these requirements. After reclassification, the main land use types included farmland (39.30\%), typical grassland (32.60\%), meadow grassland (13.09\%), deciduous coniferous forest and deciduous broad-leaved forest (8.90\%), bush wood (5.05\%), evergreen forest $(0.86 \%)$, barren land $(0.09 \%)$, water body $(0.05 \%)$, and rural villages $(0.05 \%)$ [35].

The soil data included the spatial distribution and physical and chemical attributes of the soils. The soil map was produced based on the 2005 soil survey of the study area. The physical attributes of the soils mainly included the thicknesses, silt contents, clay contents, bulk densities, organic carbon contents, effective water contents, saturated hydraulic conductivities, and the available field capacities. These attributes control the movement of the water and air in the soil and have an important role in the water cycles. This study established a users' soil parameter database based on these characteristics.

The soils were divided into four hydrologic groups. For the same precipitation and surface conditions, soils with similar runoff production capacities were classified into a single hydrologic group [39].

The wet density of a soil, the available effective water in a soil layer and the saturated hydraulic conductivity coefficient can be calculated using the SPAW model [34,35]. The SPAW model is a daily hydrologic budget model for agricultural fields. It also includes a routine for the daily water budgets of inundated ponds and wetlands that utilizes the field hydrology of the watershed.

The soil erosion factor $(\mathrm{K})$ is often used to evaluate soil erodibility. $\mathrm{K}$ is calculated based on the organic carbon and particle compositions of the soil using the method proposed by Williams [40].

The observed meteorological input data mainly included the precipitation, daily maximum and minimum temperature data from 2001 to 2010. The SWAT model includes a built-in weather generator. If some data were not available, the weather generator simulated daily meteorological data based on multi-year monthly mean data that were provided in advance. The "pcpSTAT" and "dew02" procedures were used to calculate daily precipitation and temperature to obtain the related parameters and generate the weather data that were needed for simulations.

The measured runoff and sediment data were collected at ZHS (Figure 2) from 2001 to 2010. They were used in sensitivity analysis and parameters calibration. The measured daily precipitation data were used to simulate daily runoff using the Soil Conservation Service (SCS) curve method [39]. The potential evaporation was derived using the Penman-Monteith method [41]. The variable storage coefficient method [42] was used in the river channel routing simulation. 


\subsubsection{Sensitivity Analysis, Validation, and Testing of the SWAT Parameters}

The parameter sensitivity analysis module was used to analyze the sensitivities of the parameters in the runoff and sediment simulations. This module uses the Latin hypercube one-factor-at-a-time (LH-OAT) method [43]. The objective of this analysis is to analyze and determine which input parameters have the most significant impacts on the output when their values are changed. Important parameters are selected to highlight their impacts on the simulation and to reduce the time that is needed for parameter adjustment. In this study, the simulated runoff and sediment yield were compared with actual gauged data at ZHS (Figure 2). The important factors affecting the precision of the simulation in the watershed were determined after analyzing the sensitivity of each parameter.

The runoff and sediment yield parameters were calibrated in sequence. Three indexes, including the relative error $(R e)$ [44], the coefficient of determination $\left(R^{2}\right)$ [45] and the Nash-Sutcliffe coefficient (Ens) [46] were chosen to statistically test the accuracy of the calibrated and validated runoff and sediment yield outputs. If $R e=0$, the model prediction is the same as the observed data. If $R e>0$, the model prediction is larger than the observation. If $R e<0$, the model prediction is less than the observed value. $R^{2}$ was obtained from the linear regression in Microsoft Excel. The larger the $R^{2}$ value, the better simulation of the model. If the value of Ens is greater than 0.75 , the simulation is excellent. If Ens is between 0.36 and 0.75 , the simulation is satisfactory, and if Ens is less than 0.36 , the simulation is unsatisfactory.

\subsection{Precipitation Scenarios}

Based on land use maps in 2005 and the climate conditions from 2001 to 2010, the calibrated and verified SWAT model was used to simulate the impacts of precipitation on the runoff and sediment yield by altering the input climate conditions (precipitation). Spatial variability in precipitation was not considered in the simulations because the study area is a small watershed with limited precipitation stations.

Precipitation scenarios were determined based on the variation characteristics of the precipitation in this area. During the study period, the annual precipitation did not show significant increasing or decreasing trend in this area. A previous study [47] also showed no significant increasing or decreasing trend in the Yanhe River basin. The mean annual precipitation in the study area from 2001 to 2010 was $514 \mathrm{~mm}$. Thus, we considered four precipitation change scenarios:

(1) the annual mean precipitation increases by $20 \%$, i.e., $617 \mathrm{~mm}$;

(2) the annual mean precipitation increases by $10 \%$, i.e., $565 \mathrm{~mm}$;

(3) the annual mean precipitation decreases by $10 \%$, i.e., $462 \mathrm{~mm}$; and

(4) the annual mean precipitation decreases by $20 \%$, i.e., $411 \mathrm{~mm}$.

\subsection{Variance Analysis}

The coefficient of variation $(C v)$ was used to reflect the inter-annual changes in the precipitation and runoff. It is calculated using the following equation:

$$
C v=\frac{S D}{M}
$$


where $S D$ is the standard deviation of a variable and $M$ is the average value of the variable. The greater the value of $C v$ of precipitation or runoff, the greater the extent of the inter-annual change in the precipitation or runoff is, and the possibility of occurrences of floods or droughts increases. The smaller the value of $C v$ of the inter-annual precipitation or runoff is, the smaller the extent of the inter-annual change in the precipitation or runoff is, which is more beneficial to the utilization of water resources. $C v$ also reflects the characteristics of the inter-annual change in the sediment yield. The greater the value of $C v$ of the sediment yield indicates that the sediment yield changed greatly, and disasters such as soil erosion are more common. On the other hand, the smaller the value of $C v$ of sediment yield is, the smaller changing extent of the sediment yield is, which is more beneficial to water and soil conservation.

The changing rate $(C R)$ is another parameter that expresses the changes in the runoff and sediment yield:

$$
C R=\frac{X_{i}-X_{0}}{X_{0}} \times 100 \%
$$

where $X_{i}$ represents the simulated annual mean runoff or sediment yield under the $i$ th precipitation scheme, and $X_{0}$ represents the simulated annual mean runoff or sediment yield under the actual conditions.

\section{Results}

\subsection{Characteristics of the Variations of Runoff and Sediment Yield}

The Xichuan Watershed is in a continental monsoon climate region. The runoff mainly originates from precipitation and is thus significantly affected by precipitation. With the data measured at the ZHS between 2001 and 2010, the changes in the runoff and sediment yield in the watershed during this 10 -year period were analyzed and compared with precipitation changes.

Figure 3 shows the distributions of the monthly mean precipitation and runoff between 2001 and 2010. The precipitation and runoff are both concentrated in the flood season (from June to September). The most intense monthly precipitation occurs in July, which accounts for $20.4 \%$ of the annual total, and the maximum monthly runoff occurs in August, accounting for $20.1 \%$ of the total annual runoff. The minimum monthly precipitation occurs in December $(0.75 \%$ of the total annual precipitation), and the minimum monthly runoff occurs in January (3.38\% of the total annual runoff). The seasonal precipitation and runoff distributions in the watershed are extremely uneven. Precipitation and runoff are mainly concentrated in the summer and fall. Summer precipitation accounts for $54.3 \%$ of the total annual precipitation, and summer runoff accounts for $45.7 \%$ of the total annual runoff. Fall precipitation accounts for $27.7 \%$ of the total annual precipitation, and fall runoff accounts for $23.3 \%$ of the total annual runoff. Figure 3 also shows that, during the spring and winter, the changes in the precipitation and runoff are gentle, and the precipitation and runoff are relatively stable. The runoff is slightly affected by precipitation during this period. Generally speaking, the runoff in the Xichuan Watershed is mainly generated by the base flows in the spring and winter and by precipitation in the summer and spring. 


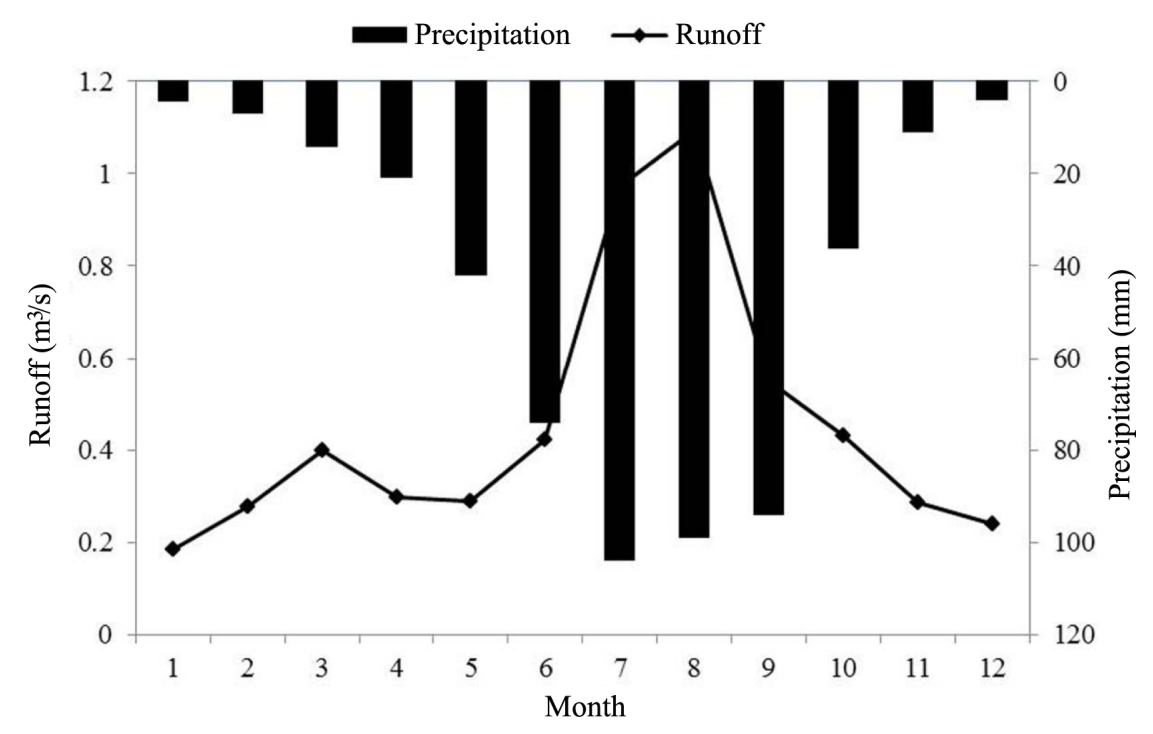

Figure 3. Comparison of the monthly measured runoff and precipitation.

Figure 4 shows the distributions of the monthly mean precipitation and sediment yields between 2001 and 2010. The annual sediment yield is generally consistent with the runoff pattern. The sediment yield is mainly concentrated in flood seasons. The maximum sediment output $(16,406 \mathrm{t} / \mathrm{m})$ occurs in August. Both the maximum runoff and the maximum sediment yield occur one month after the maximum precipitation. In the Loess Plateau, sediment production is usually accompanied by runoff with eroding capability. That the maximum peaks of runoff and sediment yield occurred within the same month is understandable. Besides precipitation, runoff and sediment generation processes are related to many other factors, including soil properties, topography, and land cover change. These factors are heavily influenced by human activities. In this watershed, a series of infrastructure reforms, water and soil conservation, and ecological projects, especially the well-known Grain-to-Green Program started in 1998 [48], were undertaken before and during the study period. Specific practices, including changing slopes into terrace fields, afforestation in barren land, constructing silt dams and reservoirs, returning farmland to forest or grassland etc., could retard the processes of runoff generation and soil erosion [49].

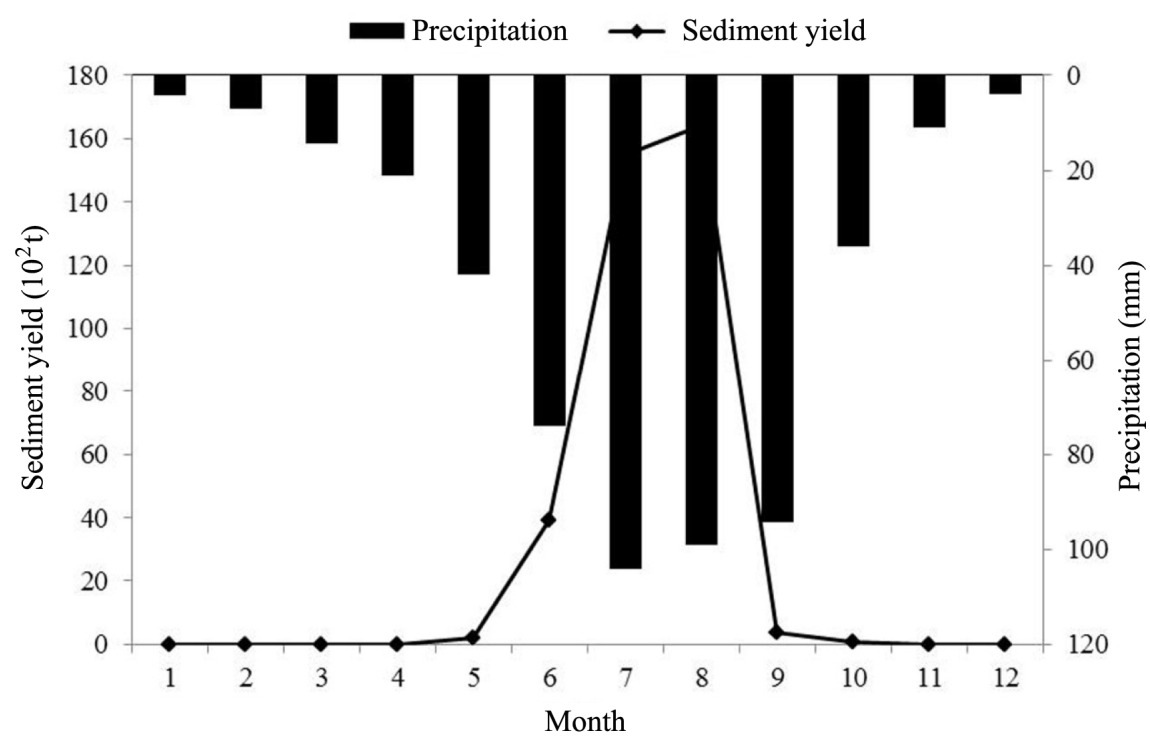

Figure 4. Comparison of the monthly measured sediment yield and precipitation. 
In general, high-intensity precipitation will affect the runoff and sediment yield in a basin only after time has passed since the precipitation. The sediment yield in the watershed is mainly concentrated in the summer because high-intensity precipitation frequently occurs in that season, and precipitation is the main source of the runoff, which is main driving force of sediment output; therefore, the runoff and sediment exhibit significant seasonal variations [9].

Inter-annual runoff changes are often affected by factors such as climate change, human activities, and changes in the underlying surface conditions. Table 2 shows the statistical characteristics of the precipitation and runoff at ZHS. The annual mean precipitation and runoff at the ZHS from 2001 to 2010 are $513.38 \mathrm{~mm}$ and $169.04 \times 10^{6} \mathrm{~m}^{3}$, respectively. The maximum precipitation at ZHS $(634.3 \mathrm{~mm})$ occurred in 2007, and the maximum runoff $\left(235.89 \times 10^{6} \mathrm{~m}^{3}\right)$ occurred in 2002 . The minimum precipitation $(441.6 \mathrm{~mm})$ and minimum runoff $\left(95.08 \times 10^{6} \mathrm{~m}^{3}\right)$ at ZHS both occurred in 2008 . The $C v$ values of the inter-annual precipitation and runoff between 2001 and 2010 are both relatively small $(0.13$ and 0.29 , respectively). Therefore, in this 10 -year period, the variation in precipitation in the watershed was insignificant, and the water resources were relatively stable, favoring the use of water resources.

Table 2. Annual characteristics of precipitation, runoff and sediment yield during 2001-2010.

\begin{tabular}{ccccccc}
\hline \multirow{2}{*}{ Variable } & Mean Value & $\boldsymbol{C} \boldsymbol{v}$ & Value & $\begin{array}{c}\text { Year of } \\
\text { Occurrence }\end{array}$ & Value & $\begin{array}{c}\text { Year of } \\
\text { Occurrence }\end{array}$ \\
\cline { 5 - 7 } & & & & 2007 & $441.60 \mathrm{~mm}$ & 2008 \\
Precipitation & $513.38 \mathrm{~mm}$ & 0.13 & $634.30 \mathrm{~mm}$ & 2002 & $95.08 \times 10^{6} \mathrm{~m}^{3}$ & 2008 \\
Runoff & $169.04 \times 10^{6} \mathrm{~m}^{3}$ & 0.29 & $235.89 \times 10^{6} \mathrm{~m}^{3}$ & $208.70 \times 10^{4} \mathrm{t}$ & 2006 \\
Sediment & $1,330.20 \times 10^{4} \mathrm{t}$ & 0.84 & $3,161.40 \times 10^{4} \mathrm{t}$ & 2002 & 122.702 \\
\hline
\end{tabular}

The sediment discharge is related to many factors, such as the topography and landforms of the basin, vegetation cover, precipitation, and precipitation intensity. In recent decades, the changes in the sediment yield in the Xichuan Watershed were relatively complicated due to the impacts of climate change and human activities. The mean sediment yield at ZHS between 2001 and 2010 is $1330.2 \times 10^{4} \mathrm{t}$ (Table 2). During 2001 to 2010, the sediment discharge changed significantly, and soil erosion was relatively severe. The $C v$ value of the inter-annual sediment discharge at ZHS between 2001 and 2010 is relatively large (0.84). The maximum sediment yield at ZHS between 2001 and $2010\left(3161.4 \times 10^{4} \mathrm{t}\right)$ occurred in the same year as the maximum runoff (2002), and the minimum sediment yield $\left(122.7 \times 10^{4} \mathrm{t}\right)$ occurred in 2006.

\subsection{SWAT Calibration and Validation Results}

In this study, the year of 2001 was used as the warming period, data in 2002-2006 was used for model calibration, and data in 2007-2010 was used for model validation. The calibration procedure follows the method introduced by [36] with the following steps:

Step 1: model initiation — run the model and read the required data and parameters;

Step 2: runoff simulation-produce the simulated monthly runoffs and compare them to the actual observed values;

Step 3: if runoff simulation reaches the condition of $-20 \%<R e<20 \%, R^{2}>0.6$, and Ens $>0.5$, then go to the next step for sediment yield simulation; otherwise, the adjust the parameters "Base flow 
recession constant," "Snow pack temperature lag factor," "Soil evaporation compensation factor," "Available water capacity," "Threshold depth of water in the shallow aquifer required for return flow to occur," and "Groundwater 'revap' coefficient" and go back to step 2;

Step 4: sediment yield simulation - produce the simulated monthly sediment yields and compare them to the actual observed values;

Step 5: if sediment yield simulation reaches the condition of $-20 \%<R e<20 \%, R^{2}>0.6$, and $E n s>0.5$, then the simulation is successfully ended; otherwise, adjust the parameters "USLE equation support practice factor," "Linear parameters for calculating the channel sediment rooting," and "Peak rate adjustment factor for sediment routing in the main channel" and go back to step 4.

Figures 5 and 6 show comparisons between the observed and simulated monthly runoffs and sediment yield at ZHS during the model calibration period. Figures 7 and 8 show the results during the model validation period. Table 3 compares the parameters of the simulated monthly runoff and sediment yield in the model calibration and validation periods.

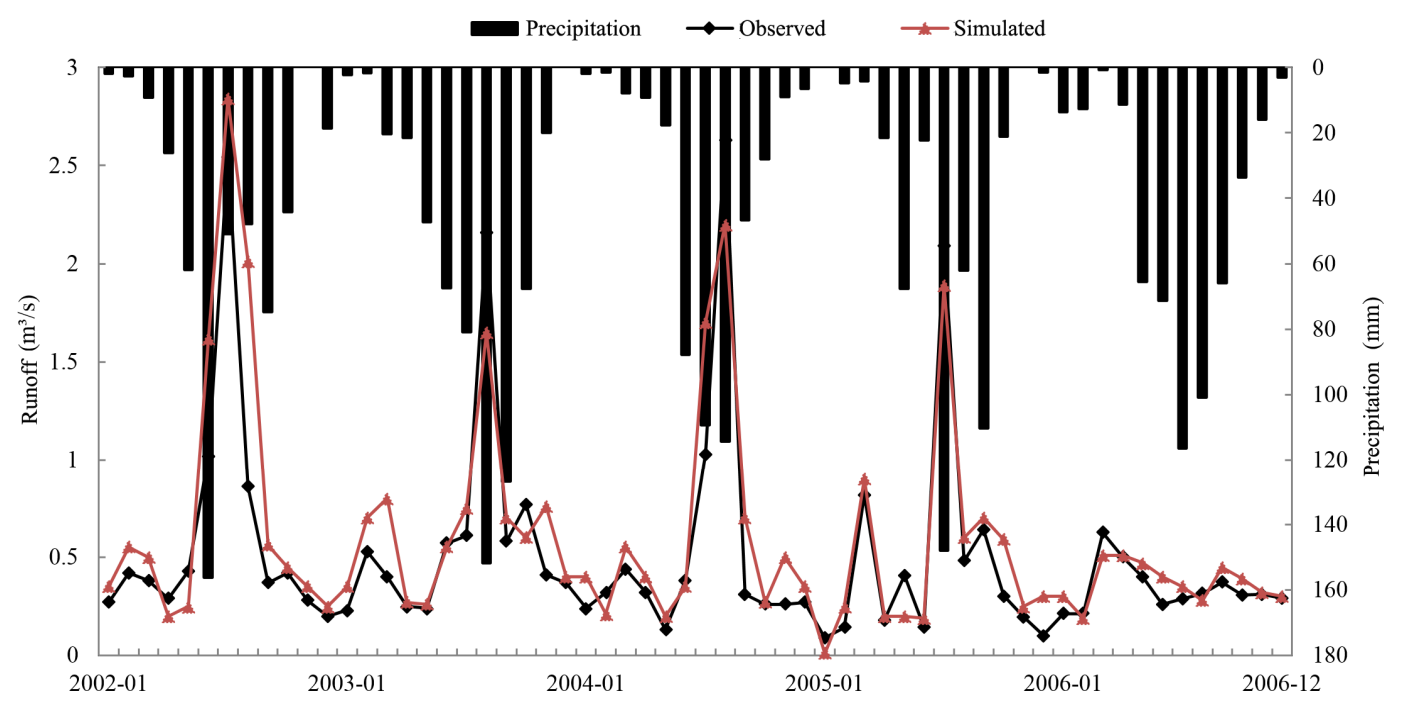

Figure 5. Comparison between the simulated and observed monthly runoff in model calibration.

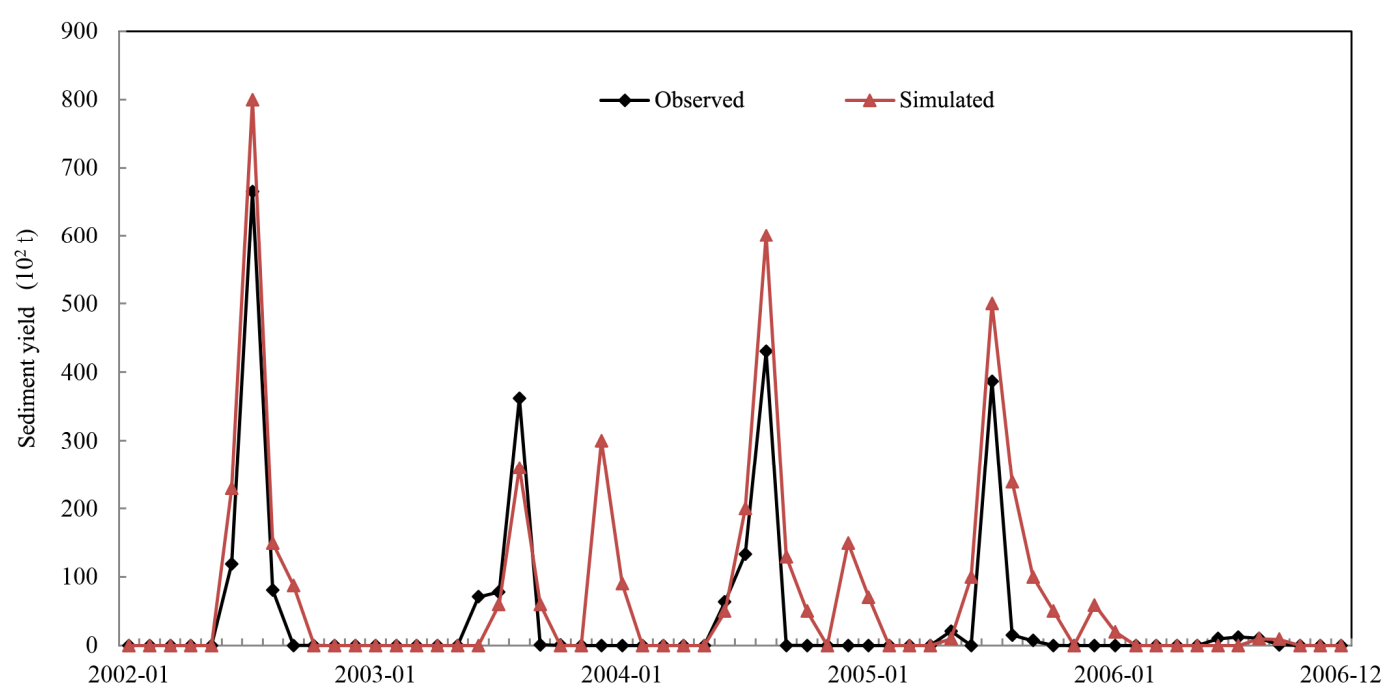

Figure 6. Comparison between the simulated and observed monthly sediment yield in model calibration. 


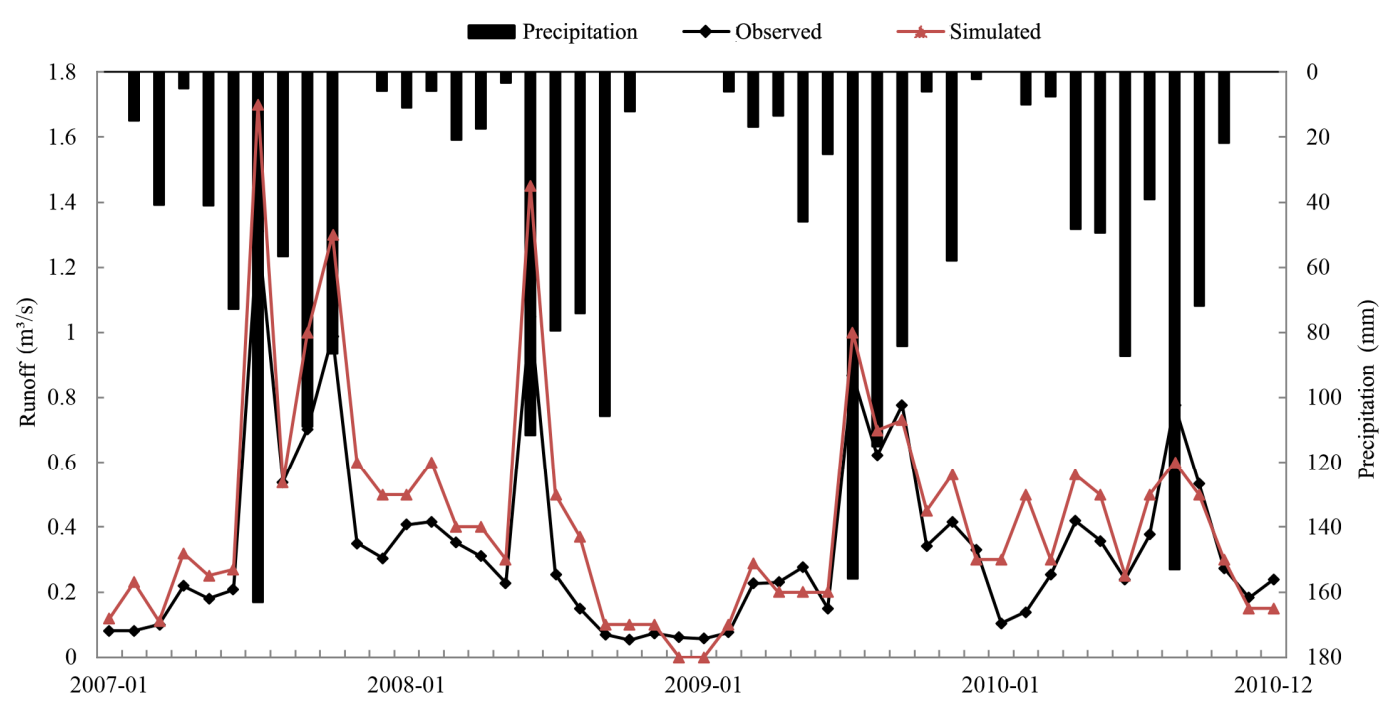

Figure 7. Comparison between the simulated and observed monthly runoff in model validation.

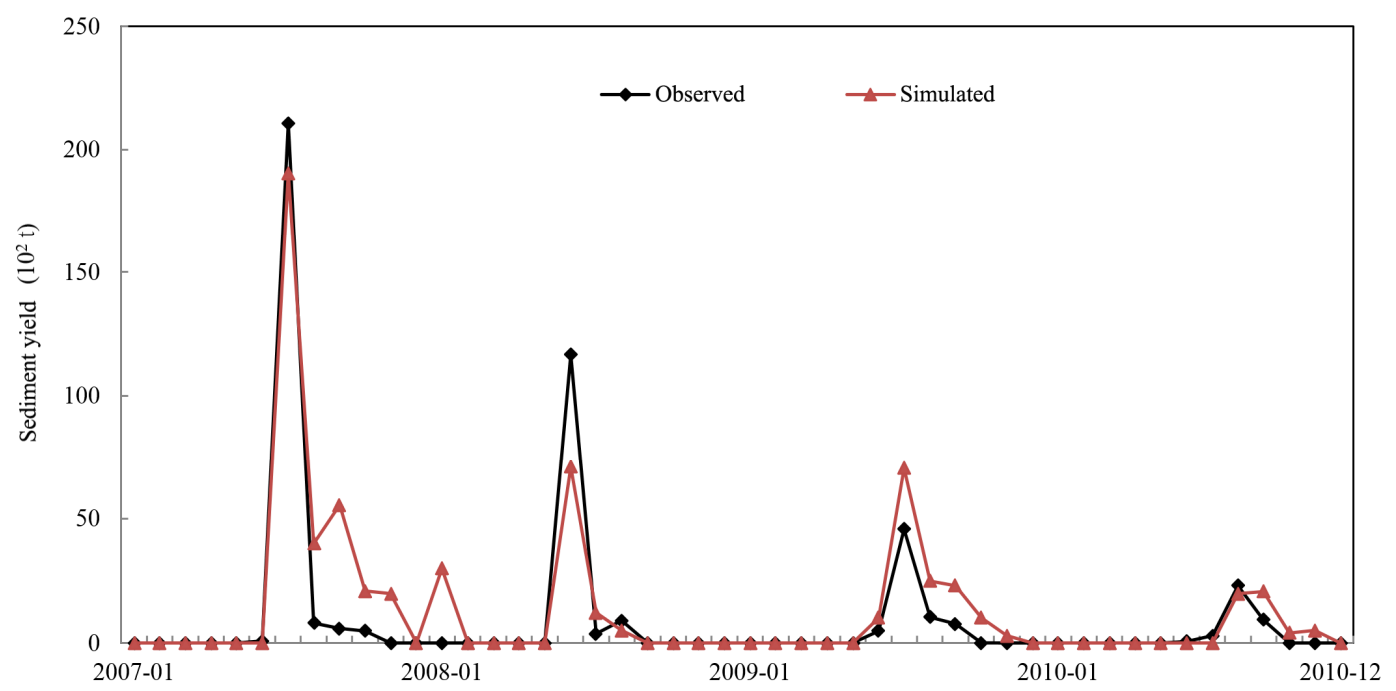

Figure 8. Comparison between the simulated and observed monthly sediment yield in model validation.

Table 3. Evaluation results of the SWAT model performance.

\begin{tabular}{ccccccc}
\hline \multirow{2}{*}{ Simulation Period } & \multicolumn{3}{c}{ Runoff } & \multicolumn{3}{c}{ Sediment Yield } \\
\cline { 2 - 7 } & $\boldsymbol{R} \boldsymbol{e}$ & $\boldsymbol{R}^{\mathbf{2}}$ & $\boldsymbol{E n s}$ & $\boldsymbol{R} \boldsymbol{e}$ & $\boldsymbol{R}^{\mathbf{2}}$ & $\boldsymbol{E n s}$ \\
\hline Calibration (2002-2006) & $9.10 \%$ & 0.79 & 0.73 & $14.20 \%$ & 0.78 & 0.67 \\
Verification (2007-2010) & $11.20 \%$ & 0.88 & 0.82 & $17.50 \%$ & 0.83 & 0.71 \\
\hline
\end{tabular}

As illustrated in Figures 5-8, the difference between simulated runoff/sediment yield and observed values is smaller during the calibration period than during the validation period, while the variation trend of runoff/sediment yield is more consistent with the trend of observed data during the validation period than in the calibration period. These differences can also be supported by the statistics in Table 3 . Table 3 also shows that in the model validation period, the values of $R e$ between the simulated and observed monthly runoffs and between the simulated and observed monthly sediment yields are $11.2 \%$ and $17.5 \%$, respectively, and the values of $R^{2}$ are 0.88 and 0.83 , respectively. The Ens values of runoffs and sediment 
yields are 0.82 and 0.71 , respectively. The SWAT simulated values generally reflect the actual changes in the runoff and sediment yield, and the SWAT model can be used for the subsequent scenario analysis.

\subsection{Responses of Runoff and Sediment Yield to Precipitation Changes}

We also simulated the runoff and sediment yields under the four precipitation scenarios described in Section 2.4. Keeping the other inputs the same, the four precipitation scenarios were input to the validated SWAT model, and the daily runoff and sediment yield were simulated for the year of 2002 to 2010. Table 4 shows the nine-year (2002-2010) mean values. Figure 9 shows the trends and changes in the runoff and sediment yield under these precipitation scenarios.

Table 4. Responses of annual runoff and sediment yield to precipitation changes.

\begin{tabular}{ccccccc}
\hline Simulated Item & Compared Value & $\mathbf{P}$ & $\begin{array}{c}\mathbf{P} \\
(\mathbf{1 \%}+\mathbf{2 0 \%})\end{array}$ & $\begin{array}{c}\mathbf{P} \\
(\mathbf{1 \%}+\mathbf{1 0 \%})\end{array}$ & $\begin{array}{c}\mathbf{P} \\
(\mathbf{1 \%}-\mathbf{1 0 \%})\end{array}$ & $\begin{array}{c}\mathbf{P} \\
(\mathbf{1 \%}-\mathbf{2 0} \%)\end{array}$ \\
\hline Runoff & Simulated value $\left(\mathrm{m}^{3}\right)$ & 156.14 & 207.20 & 184.81 & 135.28 & 112.58 \\
Sediment yield & Simulated value $\left(10^{4} \mathrm{t}\right)$ & 101.09 & 120.49 & 112.87 & 90.93 & 85.04 \\
\hline
\end{tabular}

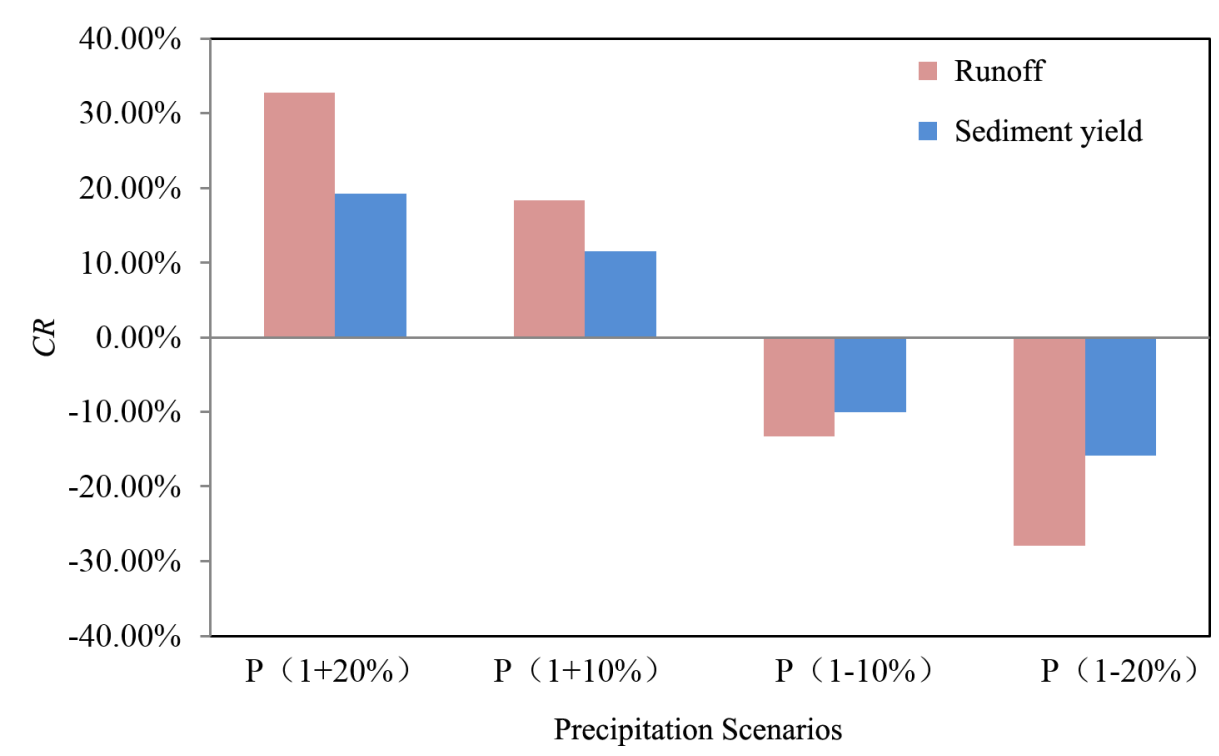

Figure 9. Changing rate of annual runoff and sediment yield change to precipitation change.

The results show that the runoff and sediment yield in this watershed under the four precipitation scenarios have the following characteristics:

(1) The runoff and sediment yield increase with increasing precipitation and decrease with decreasing precipitation, which is consistent with the actual situation. Precipitation has a direct impact on runoff, and sediment is transported by runoff. Therefore, the trends of the changes in the precipitation, runoff, and sediment are similar.

(2) When precipitation increases by $10 \%$, the runoff and sediment yield increase by $18.36 \%$ and $11.54 \%$, respectively. When precipitation decreases by $10 \%$, the runoff and sediment yield decrease by $13.36 \%$ and $10.05 \%$, respectively. The increases in the runoff and sediment yield are greater than the decreases in the runoff and sediment yield. The change in the runoff with precipitation is greater than the change in the sediment yield with precipitation. Therefore, 
precipitation has a more significant impact on the runoff than the sediment yield. The runoff generated by precipitation is only one of several factors that affect sediment production and sediment production may also be affected by other factors, such as vegetation cover, soil bulk density and land use changes.

(3) When precipitation increases by $20 \%$, the runoff and sediment yield increase by $32.7 \%$ and $19.20 \%$, respectively. Thus, water resources will become relatively abundant when the annual precipitation intensity is relatively high, so it will be necessary to focus on preventing floods and sediment loss. When precipitation decreases by $20 \%$, the runoff and sediment yield decrease by $27.9 \%$ and $15.88 \%$, respectively. In these cases, water resources will be relatively scarce and it is necessary to take measures to prevent and combat droughts.

Based on the simulation results, the $C v$ values of the annual runoff and sediment yield are statistically calculated for the four precipitation scenarios. Figure 10 shows the trends and changes in the $C v$ values of the annual runoff and sediment yield for the precipitation scenarios.

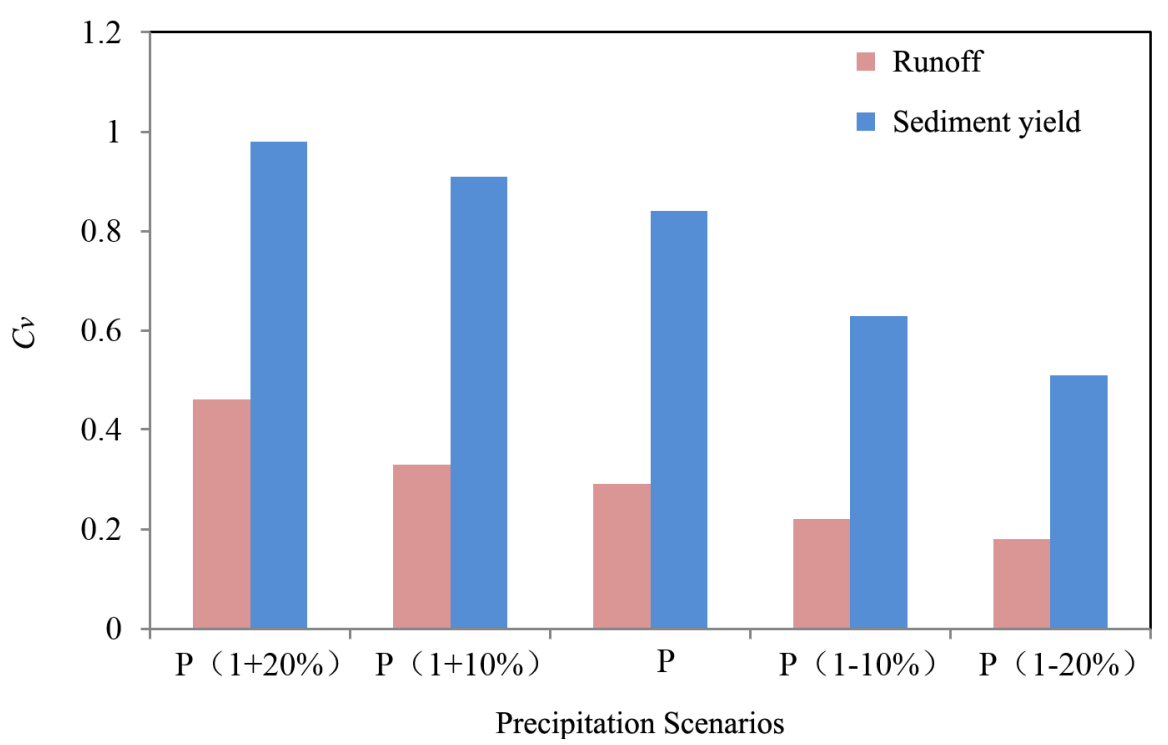

Figure 10. Coefficients of variation of annual runoff and sediment yield to precipitation changes.

The $C v$ values of the annual runoff and sediment yield both decrease with decreasing precipitation. The $C v$ values vary between 0.18 and 0.46 for the annual runoff, and vary between 0.51 and 0.98 for the sediment yield. Therefore, the $C v$ values of the annual runoff are smaller than those of the sediment yield. The decreased $C v$ value of the sediment yield with decreasing precipitation is more apparent than its increase with increasing precipitation, indicating that the $C v$ of the sediment yield is more sensitive to a decrease in precipitation. When precipitation increases by $20 \%$, the $C v$ value of the annual runoff is 0.46 and that of the annual sediment yield is 0.98 , which also demonstrates that when the precipitation intensity is relatively high, the annual runoff and sediment yield fluctuate significantly, and floods and soil erosion will occur frequently, which will be detrimental to the utilization and management of the water resources in the watershed. 


\section{Discussion}

By studying the impacts of different precipitation scenarios on runoff and sediment yield in the Xichuan Watershed, we found that the runoff and sediment yield in the basin increase with increasing precipitation and decrease with decreasing precipitation and that the increase is more significant than the decrease. Precipitation has a more significant impact on runoff than on sediment yield. However, researchers have not yet reached a consensus about whether runoff and sediment production is more sensitive to a decrease or an increase in precipitation, as well as whether runoff or sediment production is more sensitive to changes in precipitation.

In a study of the response of runoff production in the Fox Basin in Illinois (US) to changes in precipitation, Elias [19] found that runoff production is more sensitive to increases in precipitation. In an investigation of the impact of climate change on runoff and sediment production in the purple, hilly area of Sichuan Province, China, Zeng et al. [50] found that the annual mean runoff and sediment yield increased with increasing precipitation. For the same change in precipitation, the percentage change in the sediment yield was almost twice the percentage change in the runoff. The runoff and sediment yield were more sensitive to decreases in precipitation than to increases, and the changes in the runoff and sediment yield with decreasing precipitation were more significant. The surface conditions of an area can thus affect the impact of precipitation on the runoff and sediment production in the area. In addition, another important parameter of climate change, namely temperature, will affect runoff variations. In the parameter sensitive analysis, the snow pack temperature factor is the second most sensitive parameter in the SMAT model [36], which means that melting snow is an important source of precipitation in the study area. Xia et al. [51] also discovered that when the temperature varied between $0{ }^{\circ} \mathrm{C}$ and $1{ }^{\circ} \mathrm{C}$, the monthly runoff in the Hanjiang River Basin increased with increasing precipitation more than it decreased with decreasing precipitation. However, with increasing temperature, the extent to which the monthly mean runoff increased with increasing precipitation gradually decreased, whereas the extent to which it decreased with decreasing precipitation gradually increased. This might be attributed to the fact that an increase in temperature had a greater impact than precipitation on evapotranspiration in the basin.

This study uses the SWAT model to simulate changes in the runoff and sediment yield under several precipitation scenarios and preliminarily reveals the characteristics of the changes in the runoff and sediment yield in a small basin typical of the hill and gully area of the Loess Plateau. However, several problems in this study merit further research and investigation. (1) Several climate factors have impacts on runoff and sediment production. However, this study only considers the impact of precipitation and does not consider the impact of changes in temperature on the runoff and sediment production. Evapotranspiration is an important factor that affects surface runoff. Due to the lack of evapotranspiration data for the basin, it is not possible to calibrate and verify the evapotranspiration in the basin. Therefore, this study does not investigate the changes in evapotranspiration in the basin that are caused by changes in precipitation. Additional studies should be conducted to investigate the impact of other factors (e.g., temperature, evapotranspiration) on the runoff and sediment production; (2) This study did not consider the spatial distribution of precipitation that will bring uncertainty to the results of model simulation. Because the study area only covers $719 \mathrm{~km}^{2}$, the assumption of a uniform precipitation is acceptable. When the method is extended to large river basins, the spatial distribution of precipitation 
should be considered. Since the HRU is the basic spatial unit in the simulation, the spatial distribution of precipitation can be considered by inputting different precipitation data for different HRUs if more precipitation stations are available. (3) Due to the data availability, the precipitation scenarios were set using the empirical method, a method used by other researchers in this situation [21,23]. In future studies, efforts should be made to collect basic data and use climate output models to predict precipitation to conduct in-depth investigations on the trends of future climate change.

\section{Conclusions}

A SWAT model was parameterized in the Xichuan Watershed, a typical hilly and gully loess area in the Loess Plateau, China. The variations of runoff and sediment yield were simulated using the calibrated SWAT model and scenario analyses. Based on the simulation, we found that the increases of runoff and sediment yield with increasing precipitation are more apparent than their decreases with decreasing precipitation. Precipitation has a more significant impact on runoff than on sediment yield. The $C v$ values of the annual runoff and sediment yield both increase with increasing precipitation. However, the $C v$ value of the annual runoff is relatively smaller than the $C v$ value of the sediment yield when precipitation increases, and the $C v$ value of sediment yield is more sensitive to a decrease in precipitation than is that of runoff. The different characteristics of variations in runoff and sediment yield suggests proper strategies in the utilization and management of the water resources in this watershed.

\section{Acknowledgments}

This work was supported by the National Natural Science Foundation of China with Grant No. 50979003. Support from the Collaborative Innovation Center for Regional Environmental Quality is also acknowledged. Special thanks also extend to the editors and all of the anonymous reviewers.

\section{Author Contributions}

Tianhong Li conceived and designed the research, and wrote the paper; Yuan Gao analyzed the data, localized SWAT model and performed scenario analysis.

\section{Conflicts of Interest}

The authors declare no conflict of interest.

\section{References}

1. Allen, M.R.; Ingram, W.J. Constrains on future changes in climate and the hydrologic cycle. Nature 2002, 419, 224-232.

2. Oki, T.; Kanae, S. Global hydrological cycles and world water resources. Science 2006, 313, 1068-1072.

3. Dong, L.H.; Xiong, L.H.; Yu, K.X.; Li, S. Research advances in effects of climate change and human activities on hydrology. Adv. Water Sci. 2012, 2, 278-285. (In Chinese) 
4. Trenberth, K.E. Conceptual framework for changes of extremes of the hydrological cycle with climate change. In Weather and Climate Extremes-Changes, Variations and a Perspective from the Insurance Industry; Springer Netherlands: Dordrecht, The Netherlands, 1999; pp.327-339.

5. Zhang, J.Y.; Wang, G.Q. Research on Impacts of Climate Change on Hydrology and Water Resources; Science Press: Beijing, China, 2007. (In Chinese)

6. Piao, S.L.; Ciais, P.; Huang, Y.; Shen, Z.; Peng, S.; Li, J.; Zhou, L.; Liu, H.; Ma, Y.; Ding, Y.; et al. The impacts of climate change on water resources and agriculture in China. Nature 2010, 467, 43-51.

7. Barnett, T.P.; Adam, J.C.; Lettenmaier, D.P. Potential impacts of a warming climate on water availability in snow-dominated regions. Nature 2005, 438, 303-309.

8. IPCC. Climate Change 2007: Impacts, Adaptation and Vulnerability Contribution of Working Group 11 to the Fourth Assessment Report of the Intergovernmental Panel on Climate Change; Cambridge University: Cambridge, UK; New York, NY, USA, 2007.

9. Li, F.P.; Zhang, G.X.; Dong, L.Q. Studies for impact of climate change on hydrology and water resources. Sci. Geogr. Sin. 2013, 4, 457-464.

10. Song, X.M.; Zhang, J.Y.; Zhan, C.S.; Liu, C.Z. Review for impacts of climate change and human activities on water cycle. China J. Hydrol. 2013, 44, 779-790. (In Chinese)

11. Xia, J.; Liu, C.Q.; Ren, G.Y. Opportunity and challenge of the climate change impact on the water resources of China. Adv. Earth Sci. 2011, 1, 1-12.

12. Wang, G.Q.; Zhang, J.Y.; Liu, J.F.; Jin, J.L.; Liu, C.S. The sensitivity of runoff to climate change in different climatic regions in China. Adv. Water Sci. 2011, 3, 307-314. (In Chinese)

13. Arnold, J.G.; Williams, J.R.; Srinivasan, R.; King, K.W. The Soil and Water Assessment Tool (SWAT) User's Manual; USDA-ARS: Temple, TX, USA, 1995.

14. Eckhardt, K.; Ulbrich, U. Potential impacts of climate change on groundwater recharge and streamflow in a central European low mountain range. J. Hydrol. 2003, 284, 244-252.

15. Ficklin, D.L.; Luo, Y.Z.; Luedeling, E.; Zhang, M. Climate change sensitivity assessment of a highly agricultural watershed using SWAT. J. Hydrol. 2009, 374, 16-29.

16. Xu, Z.X.; Zuo, D.P.; Tang, F.F. Response of Water Cycle to Future Climate Change in Typical Watershed in the Yellow River Basin; Press of Hehai University: Nanjing, China, 2012; pp. 37-49. (In Chinese)

17. Githui, F.; Gitau, W.; Mutuab, F.; Bauwens, W. Climate change impact on SWAT simulated streamflow in Western Kenya. Int. J. Climatol. 2009, 29, 1823-1834.

18. Yu, L.; Gu, J.; Li, J.X.; Zhu, X.J. A Study of hydrologic responses to climate change in medium scale basin based on SWAT. Bull. Water Soil Conserv. 2008, 28, 152-154. (In Chinese)

19. Bekele, E.G.; Knapp, H.V. Watershed Modeling to Assessing Impacts of Potential Climate Change on Water Supply Availability. Water Resour. Manag. 2010, 24, 3299-3320.

20. Zhu, C.H.; Li, Y.K. Long-term hydrological impacts of land use/land cover change from 1984 to 2010 in the Little River Watershed, Tennessee. Int. Soil Water Conserv. Res. 2014, 2, 11-22.

21. Nowak, K.; Hoerling, M.; Rajagopalan, B.; Zagona, E. Colorado River Basin Hydro-climatic Variability. J. Clim. 2012, 25, 4389-4403.

22. Fan, Y.T.; Chen, Y.N.; Li, W.H.; Wang, H.J.; Li, X.G. Impacts of temperature and precipitation on runoff in the Tarim River during the past 50 years. J. Arid Land 2011, 3, 220-230. 
23. Cayan, D.R.; Dettinger, M.D.; Kammerdiener, S.A.; Caprio, J.M.; Peterson, D.H. Changes in the onset of spring in the western United States. Bull. Am. Meteorol. Soc. 2001, 82, 399-416.

24. Colman, R. A comparison of climate feedbacks in general circulation models. Clim. Dynam. 2003, 20, 865-873.

25. Liu, Q.; Yang, Z.; Cui, B. Spatial and temporal variability of annual precipitation during 1961-2006 in Yellow River Basin, China. J. Hydrol. 2008, 361, 330-338.

26. Lu, X.X. Vulnerability of water discharge of large Chinese rivers to environmental changes: An overview. Reg. Environ. Chang. 2004, 4, 182-191.

27. Wei, W.; Chen, L.; Fu, B.; Chen, J. Water erosion response to rainfall and land use in different drought-level years in a loess hilly area of China. Catena 2010, 81, 24-31.

28. Miao, C.Y.; Ni, J.R.; Borthwick, A.G.L.; Yang, L. A preliminary estimate of human and natural contributions to the changes in water discharge and sediment load in the Yellow River. Glob. Plenary Chang. 2011, 76, 196-205.

29. Miao, C.Y.; Ni, J.R.; Borthwick, A.G.L. Recent changes of water discharge and sediment load in the Yellow River basin, China. Phys. Geogr. 2010, 34, 541-561.

30. Ren, Z.P.; Zhang, G.H.; Yang, Q.K. Characteristics of runoff and sediment variation in the Yanhe River Basin in last 50 years. J. China Hydrol. 2012, 32, 81-86. (In Chinese)

31. Sui, J.; He, Y.; Liu, C. Changes in sediment transport in the Kuye River in the Loess Plateau in China. Int. J. Sediment Res. 2009, 24, 201-213.

32. Li, Z.; Liu, W.Z.; Zhang, X.C.; Zheng, F.L. Impacts of land use change and climate variability on hydrology in an agricultural catchment on the Loess Plateau of China. J. Hydrol. 2009, 377, 35-42.

33. Luo, H.M.; Li, T.H.; Ni, J.R.; Wang, Y.D. Water Demand for Ecosystem Protection in River with Hyper-concentrated Sediment-laden Flow. Sci. China Ser. E 2004, 47, 186-198.

34. Saxton, K.E. Soil Water Characteristics Hydraulic Properties Calculator [EB/OL]. Available online: http: //www.bsyse.wsu.edu/saxton/soilwater (accessed on 20 March 2004).

35. Saxton, K.E.; Willey, P.H.; Rawls, W.J. Field and pond hydrologic analyses with the SPAW model. In Proceedings of the Annual International Meeting of American Society of Agricultural and Biological Engineers, Portland, OR, USA, 9-12 July 2006; pp.1-13.

36. Gao, Y.; Li, T.H. Responses of runoff and sediment yield to LUCC with SWAT model: A case study in the Xichuan River Basin, China. Sustain. Environ. Res. 2015, 25, 27-35.

37. Bai, Y.M. Effect of returning farmland to forests to benefit of soil and water conservation in Xichuanhe River basin. J. Water Resour. Water Eng. 2011, 22, 176-178. (In Chinese)

38. Liu, K.W. River Systems in Yanan City; Press of Yan'An Education College: Yan'an, China, 2000. (In Chinese)

39. USDA (United States Department of Agriculture). Urban Hydrology for Small Watersheds: TR-55; No. 210-VI-TR-55; Government Printing Office: Washington, DC, USA, 1986.

40. Williams, J.; Nearing, M.; Nicks, A.; Skidmore, E.; Valentin, C.; King, K.; Savabi, R. Using soil erosion models for global change studies. J. Soil Water Conserv. 1996, 51, 381-385.

41. Chiew, F.H.S.; McMahon, T.A. The applicability of Morton's and Penman's evapotranspiration estimates in rainfall-runoff modelling. Water Resour. Bull. 1991, 27, 611-620.

42. Williams, J.R. Flood routing with variable travel time or variable storage coefficients. Trans. ASAE 1969, 12, 100-103. 
43. Van Griensven, A.; Meixner, T.; Grunwald, S.; Bishop, T.; Diluzio, M.; Srinivasan, R. A global sensitivity analysis tool for the parameters of multi-variable catchment models. J. Hydrol. 2006, 324, 10-23.

44. Nagelkerke, N.J.D. A Note on a General Definition of the Coefficient of determination. Biometrika 1991, 78, 691-692.

45. Quinlan, J.R. Learning with continuous classes. In Proceedings of the AI'92, the 5th Australian Joint Conference on Artificial Intelligence, Tasmania, Australia, 16-18 November 1992; Adams, A., Sterling, L., Eds.; World Scientific: Singapore, 1992; pp. 343-348.

46. Nash, J.E.; Sutcliffe, J.V. River flow forecasting through conceptual models. Part I-A discussion of principles. J. Hydrol. 1970, 10, 282-290.

47. Yue, B.J.; Shi, Z.H.; Fang, N.F. Evaluation of rainfall erosivity and its temporal variation in the Yanhe River catchment of the Chinese Loess Plateau. Nat. Hazards 2014, 74, 585-602.

48. Fu, B.J.; Wang, Y.F.; Lu, Y.H.; He, C.H.; Chen, L.D.; Song, C.J. The effects of land-use combinations on soil erosion: A case study in the Loess Plateau of China. Prog. Phys. Geogr. 2009, 33, 793-804.

49. Zhu, L.Q.; Zhu, W.B. Research on effects of land use/cover change on soil erosion. Adv. Mater. Res. 2012, 433, 1038-1043.

50. Zeng, Y.; Wei, L. Impacts of Climate and Land Use Changes on Runoff and Sediment Yield in Sichuan Purple Hilly Area. Bull. Water Soil Conserv. 2013, 33, 1-6. (In Chinese)

51. Xia, Z.H.; Zhou, Y.H.; Xu, H.M. Water resources responses to climate changes in Hanjiang River basin based on SWAT model. Resour. Environ. Yangtze Basin 2010, 19, 158-163. (In Chinese)

(C) 2015 by the authors; licensee MDPI, Basel, Switzerland. This article is an open access article distributed under the terms and conditions of the Creative Commons Attribution license (http://creativecommons.org/licenses/by/4.0/). 